\title{
The Impact of Resistance to Change on the Implementation of Quality Management System in the Ministry of Education \\ (General Directorate of Education in South Batinah Governorate as a Model)
}

\author{
Mr. Hamed Salim Said AL Basami \\ Master of Business Administration, Ministry of Education, Oman \\ Email: hbasamii@gmail.com
}

\begin{abstract}
:
This study is investigating the reality of resistance to change in the light of Quality Management System (QMS) implementation in the Ministry of Education (South Batinah Directorate as a model of the study). It tries to answer some questions related to the main factors that lead to resistance to change with correlations of gender, years of experience and educational level. The method of collecting data of this study was conducting quantitatively through an electronic questionnaire including 59 participants of directors in different administrative level. The data has been analyzed statistically through SPSS. The result shows that the performance of the employees was impacted through the lack of awareness of the QMS requirements. Although, the all four factors recorded close level of resistance, the cognitive rigidity factor recorded the highest factor that lead to resistance to change. The study results can be generalized to other directorates in the Ministry of Education because the similar work environment. This study can be used to make some very crucial amendments in the future in managing QMS in the organization.
\end{abstract}

Keywords: Quality Management, Change management, Resistance to change, Quality Management system 


\section{ملخص الاراسة}

تبحث هذه الدر اسة في واقع مقاومة التغيير في ضوء تطبيق نظام إدارة الجودة (QMS) في وزارة التربية والتعليم (مديرية جنوب الباطنة نموذجاً). بحيث تحاول الدراسة الإجابة على بعض الأسئلة المتعلقة بالعو امل الرئيسية التي نؤدي إلى مقاومة التغيير ضمن متغير ات الجنس وسنوات الخبرة والمستوى التعليمي. واعتمدت الدراسة طريقة جمع البيانات الكمية من خلال استبيان شمل 59 مشاركاً من المدر اء ورؤساء الأقسام في مختلف المستويات الإدارية. ونم تحليل البيانات إحصائياً من خلال برنامج . SPSS ، حيث أظهرت النتيجة أن أداء الموظفين قد نأثر من خلال تدني مستوى الوعي بمتطلبات تطبيق نظام إدارة الجودة؛ على الرغم من أن جميع العوامل الأربعة سجلت مستوى قريبًا من المقاومة ، إلا أن عامل الصلابة المعرفية و الثبات المعرفي سجل أعلى مستوى من بين بقية العوامل التي أدت إلى نشوء مقاومة التغيير في حال التعامل مع مستجدات العمل المتمثلة في تطبيق نظام إدارة الجودة. كما أن نتائج الدراسة يمكن تعميمها على المديريات الأخرى في وزارة التربية و التعليم نظر البيئة العمل المماثلة من حيث ثقافة المؤسسة والأئر الاجتماعي و النفسي وكذلك المنظومة الإدارية. كذلك فإن نتائج الدر اسة يمكن استخدامها لإجر اء بعض التعديلات الحاسمة والجوهرية في المستقبل و إدخالها على مسار ات إدارة تطبيق نظام إدارة الجودة في المؤسسة التربوية. الكلمات المفتاحية: إدارة الجودة، إدارة التغيير، مقاومة التغيير، نظام إدارة الجودة

\section{Introduction}

The application of quality management is one of the main adoptions in quality management principles, methodologies and act as tools in the educational system. The concept of quality management is derived from the industry and equally helpful for educational institutions and systems to gain competitive advantage (Pratasavitskaya and Stensaker, 2010). In some cases, this is argued to have no connections with educational institutions but in the last two decades this topic has gained substantial attention from researchers. The outcomes of such researches have established quality management practices as vital for organizational sustainability and competitive advantage (UNESCO, 1998).

Quality as a heart of education has the ability to impact the outcomes of an educational institution. Almost all the developing countries are struggling to ensure that students achieve learning outcomes through acquiring values and skills. The knowledge acquisition helps them to become valuable citizens who can actively take part in nation-building. Therefore quality management in education is an integral part of the policies in many of the countries. 
The policies of the government of Oman related to the improvement in education imply that the government recognizes that the overall education system does not match with global Quality standards. Based on this justification increased focus on the quality of the educational institutions and overall system has been encouraged. Traditionally, institutions are assumed to maintain quality by their internal resources under a broad clarification and objectives of improving institutions and educational process. Education has to be about quality and excellence rather than the quality of shared time with students, teachers, systems, and stakeholders. The system of quality entails a process of activities for the administration of an institution under certain procedures and evaluation models. In many countries the issue of quality management has been an education for the masses is under the policy of high accountability in order to maintain the desired level of achievement of learning through the education system of that country (Becket and Brookes, 2008).

The overall governance structure, enrolment rates, and changing needs of outcomes of education put forth the emphasis on the existence of a quality management system. The process of quality management in educational institutions has defined new roles and functions, technical, and managerial engagements. Therefore, having a quality management evaluation process and mechanism has a vital role in assessing the function of education institutions by multidimensional approach (Yusof \& Aspinwall, 2001).

Middle East educational system is now encountering numerous changes in different ranges of life that requires corporate and private organizations to alter their conventional organization and administration styles. In this way, it is required that each organization embrace cutting edge administration concepts in the event that they crave to realize their destinations more promptly. These changes will increase their competitive edge within the worldwide inter-institutional efficiency and quick innovative improvement within the world in different regions, particularly in communication and teaching learning technologies. Improving the performance of educational institutions has become a worldwide concern in all nations within the world. Among the foremost imperative characteristics that recognize GCC countries, is their focus on economic development through long term economic plans. Thus education has been given among top priorities in developing the human capital. 
Hence, quality management in educational institutions need the participation of employees and governing bodies in order to ensure the achievements of outcomes (Al- Khatib, 2011).

This research is conducted to find out the effects of resistance to change on the implementation of Quality Management System in the Ministry of Education in Oman, (General Directorate of Education in South Batinah Governorate as a model). The literature review will be conducted to discuss the topic in detail and the researcher will identify the methodologies that he will use in this research. Different methods of data collection and recommendations will also be discussed to find out the answers of the research in detail (Alhaqbani, 2016).

Quality management systems are actually coordinated activities that help to produce specified and desired results. Customer needs can be fulfilled easily by adopting these procedures very carefully. The focus of every organization is to satisfy its customer needs which are the basic and most important parts of every organization in the short and long run both (Andrade, 2017).

During the previous two decades, researchers have reported many factors contributing to raising concerns over the quality management of the educational institutions. The new urgencies of change in educational management have pushed learning to the emergence of quality management (Cardoso, 2010). Quality management systems are actually coordinated activities that help to produce specified and desired results. Customer needs can be fulfilled easily by adopting these procedures very carefully. The focus of every organization is to satisfy its customer needs which are the basic and most important parts of every organization in the short and long run both (Andrade, 2017).

\subsection{Statement of the Problem}

Many natural factors and forces are exerting pressure for adopting change management in the educational system of nations in order to improve the outcomes of learning. Such changes have led to a greater transformation in educational management and this drive has emerged as part of long term plans of the countries. The dynamics of the quality management system have changed the organizational administrative philosophy. Therefore, this has been attempted inside the national policy setting despite the truth that education is progressively in evolution globally. In the context of Oman, 
This study questions what facts relate to current approaches to quality administration in educational institutions. Ali et al.(2015) uncovered some dimensions of the concept that add up to quality administration and the communication with education institutions in Oman. The implementation of quality management relies on directors, staff, and their staff where they have become preparing programs within a regulatory framework.

According to a research of the Ministry of Education in Oman reported by Wyatt \& Atkins (2009), "the educational research in Oman encountered by the challenges of conducting investigate at a remove, a few of the authors in this volume were exceptionally creative, and actual". Therefore, the current endeavor merits research on this topic to investigate the realities of change implementation and resistance to it.

Therefore, research evidence on educational institutions in Oman provides the rationale of this research that underpins the usage of quality management concepts in Omani educational institutions at the school level. The obvious outcomes of the research will enlighten the meaning of quality management, factors of resistance to this change and their impact on quality management in $(G D O E)$ in South Batinah in Oman.

\subsection{Research context}

Sultanate of Oman is a member of the Gulf Cooperation Council "(United Arab Emirates, Saudi Arabia, Kuwait, Oman Qatar, and Bahrain)". The education system of the country was established formally during the decades of the 1970s and the 1980s. In 1997, the Ministry of education announced its reforms programs to gradually replace the education system and organized basic education into two cycles. The first cycle grades 1 to 4 and the second cycle grades 5 to 10 followed by two years of post-basic education secondary education, grades 11 and 12 (Ministry of Education, 2004). Issan and Nariman (2010) categorized the beginning of the first stage in 1970, for rapid development of education both qualitative and quantitative. The second stage started in the 1980s with a focus on the quality and the third stage started in 1995, under "Vision of Oman's economy 2020". Further, the strategic plan (2001) was introduced to restructure the secondary education system to ensure that students will be adequately prepared for the requirements of higher education and the labor market. 
Eleven regional directorates of education "(Muscat, Batinah North, Batinah South, Dakhliyah, Sharqiah South, Sharqiah North, Dhahirah, Al Buraimi, Musandam, Al Wusta, and Dhofar)” comprise the entire structure of administrative shape of the schools' education system in Oman. Each directorate is authorized to administer and manage education in the region under the supervision of the Ministry of Education. The government has always shown firm commitment for improvement by quality management system (QMS) as a means toward producing the quality of education and administration of schools. The suitability of education is one of the main concerns to cater to needs of youth and employment entities by developing teamwork, presentation skills, problem-solving, and critical thinking (Ministry of Education and World Bank, 2012).

The post 2010 period experienced substantive activity within the advancement of educating, creation of official bodies, and instructing collaborative efforts for the improvement of education. Progressively, schools were given the independence to run their preparing programs, and this included the advancement of educational modules, collaborative activities that draw on their claim capacity of nearby educator learners, and preparing programs. Schools were brought in line with national and key activities, and general activity focused on self-sufficiency activities through quality management (Nasser, 2019).

\subsection{Research Questions}

The research intends to answer the following questions in measuring the resistance to the implementation of Quality Management System (QMS) in the General Directorate of Education (GDOE) of South Batinah in Oman.

RQ1: What is the level of resistance to Implementation of Quality Management System (QMS) in the (MOE) based on staff and directors' perceptions?

RQ2: What are the factors that account higher to resistance to change?

RQ3: Is there any significant difference in opinion regarding resistance to Implementation of Quality Management System (QMS) in the (MOE) according to years of experience?

RQ4: Is there any significant difference in the opinion regarding resistance to Implementation of Quality Management System (QMS) in the (MOE) of South Batinah according to educational level? 


\subsection{Research objectives:}

The main objective of this study is to investigate the current reality of resistance to change in Implementation of the Quality Management System (QMS) in the General Directorate of Education (GDOE) of South Batinah in Oman. The specific objectives of the research are as follows:

1. To assess the level of resistance to Implementation of Quality Management System (QMS) in the $(M O E)$ by directors and staff perceptions.

2. To find out the factors of resistance that account higher to resistance and make recommendations to overcome the issue of resistance

3. To investigate the significant difference in the opinion regarding resistance to the implementation of Quality Management System (QMS)based on years of experiences.

4. To investigate the significant difference in opinion regarding resistance to Implementation of Quality Management System (QMS) according to years of educational level.

\subsection{Significance of the Study}

Quality management in educational administration is gotten a significant consideration from the regulatory administration and scholarly analysts. This research is significant in the following ways.

- Distinctive opinions are there about the plausibility of selection in higher instruction teach between a few higher instructive teach in Oman, and a few investigates and thinks about around, it still fair to address a topic that has not gotten proper way for the correct and compelling application.

- The research will explore the facts related to changes in school administration approaches over time after quality management drive in Oman., which will reflect proficient quality management in the (MOE) in Oman.

- The research will provide a valuable theoretical contribution to further research in this area of study. Therefore, the exceptionally reason for conducting this research is to assist educational institutions to actualize quality management concept, that's when connected, with solid administrative support. The outcomes of research might be leading in guiding a continuous development in the administration framework and figure out the impact of resistance on the Quality Management System. 
- The research will be helpful for policy-makers to evaluate their regulatory and policy frameworks to improve the assurance of quality system.

- Finally, the research is not a remote but active research that will utilize field study in the real context of the phenomenon under the study.

\subsection{Scope of the Research}

The current study has investigated the impact of resistance to change on implementing a quality management system (QMS) by the Ministry of Education specifically in General Directorate of Education (GDOE) in South Batinah in Oman. The field study of this research is applicable to GDOE only. The study has tried to cover as much as possible participants from the South Batinah governorate in a convenient way. Therefore, as an outcome of the study cannot be generalized the results other than the context of Oman but closely related to other studies in a similar topic.

\subsection{Definitions}

\section{- Quality Management}

Quality management is a process that oversees all activities and tasks needed to maintain the excellence of an organization. The main task is to determine a quality policy, creating and implementing quality planning. Finally, assurance through quality control and quality improvement following the organizational process (Sallis, 2014).

\section{- Change management}

Change management is known as the organizational process, tools and techniques to manage institutional functioning. One side of the change management is the people side of change that focuses on the people impacted by the change. Other side is processes, systems, organization structures and roles along with technical tools (Todnem, 2005).

\section{- Resistance to change}

Resistance to change is the attitude of individuals. This refers to certain actions taken by individuals and groups that hinder the implementation of change because people perceive change as a threat to them (Todnem, 2005). 


\section{- Quality Management system}

The quality management system (QMS) contains policies, processes and procedures. These procedures are essential for the execution through deployment in the core of functional areas of an organization to assure the achievement of desired outcomes (Sallis, 2014).

\section{Literature Review}

\subsection{Change Management}

Change management is the process, tools and techniques to manage the people in order to make business functions smoother. Change management has a focus on the people that may impact the change. Any type of changing in systems, processes, organization structures and/or job roles will focus on two types; technical side and employee side. The main function of the change management process is to make ensure, that standards and procedures set by the company are used for efficient and prompt handling of all changes, to reduce the possible impact of changerelated experiences upon consequently improve the day-to-day operations of the organization and on service quality (Anderson, \& Anderson, 2010). Components or tools of change management are: Communication and communication planning, Readiness assessments, sponsor roadmaps, Sponsor activities, and management training for change management. Basically, there are three different types of change management: transitional, developmental, and transformational. It is very much essential to identify these. As different kinds of changes are required for different plans and strategies; in order to gain engagement, ease acceptance and reduce resistance (Cameron \& Green, 2019). Although evidence suggests that many of the business process reengineering programs have been failed, because of less alignment with corporate levelstrategy. Significant changes should be strengthened by findings and results. Individual plans with quantifiable outcomes need to enforce for expected desire results. Employees who meet their targets should be remunerated properly and those that don't have to confront results (Sikdar and Payyazhi, 2014).

\subsection{Change Management in Educational Institutions}

Change management in educational institutions is a philosophy along with certain procedures. Otherwise, there are as of now a few cases that account for the applicable regulation. Quality appraisal models coordinate see on maintaining quality system through administration, driving 
to persistent quality change. The available models of quality management propose to survey education as a whole, counting not as it were its instructing and investigate models, but moreover other exercises, and, excellently, organization administration (Sarrico et al., 2010). A comprehensive transformation is led by a change in the organization. This transformation has social, economic and cultural aspects. Regarding a specific culture and structure of the organization, the transformation is from traditional to the modern approach. The use of new managerial approaches, methods and resources provides bases for new roles of people as well. In the education sector, the ultimate destination of change management is to achieve predefined outcomes of learning of students and organizational governance and administration. Therefore, change management in education works on three level outputs (i.e. student's learning outcomes, governance, and administration of institutions). Change process proceeds towards outcome through means and creates challenges (Alibabić, 2010)

Numbers of educational systems have tried quality administration models initially created for the educational sector. A key advantage of all the models is to embrace a key approach to quality assessment and administration. The entire model of quality management is measurement, assessment and outcome-based. When this becomes a question of management, this tends to figure out the ways to be implemented. Mostly such approaches are closely linked with the work of organizations and institutions that are changing. The process of change with its implementation is the influence of the environment, or by the auditing bodies (Pratasavitskaya and Stensaker, 2010).

The inherent difficulty in quantifying theeducation for self-assessment purposes is approach increased focus on the administrative aspect for implementation. At the phase of the assessment of the outputs, the applicability of quality implementation models comes up with their shortcomings and pitfalls. The main outcome product of the educational system is the learning of students which is believed to be neglected in many cases. Quality control management should give attention to the student learning experience which is the main focal point in fact.

\subsection{Organizational changing pressures}

The ever-changing expectations of stakeholders and patterns of institutions globally demand change. 
The turbulent outside environment and energetic inner environment are similarly true blue strengths for instructive organizations as well due to the reality non-profit businesses (schools) also experiencing innovative, basic, financial and social adjustments rather like the case (Levin, 1993). Furthermore, data sharing since of globalization, and verbal trade innovation, statistic changes drastically powers individuals to trade appropriately (Ragsdell, 2000).

Really a few basic outside triggers started out of entryways the organization many be positioned as control as approaches of the government, prerequisites and values, statistics characteristics. Another issue is social and political weights made by dominant political and social occasions for the competitiveness of educating (Dawson, 2003; Kreitner \& Kinicki, 2010).The encountering forces may be internal or external as internal factors that belong to the inner body of the organization and encourages organizational proposed change. Leavitt (1964) proposed these forces as following.

1. Technology (. technology and tools to assist the process)

2. Basis functions (important tasks of organizational operations)

3. People (human resources of the organization)

4. Administrative structures (lines of communication, hierarchy, reporting pattern, rewards, style of leadership and disciplinary procedures).

Therefore, both human resources and behavior of management can be regarded as key factors in change management (Kreitner \&Kinicki, 2010).

\subsection{Change and Leadership}

This shows the relationships between the change types and methods in management and how this relationship can affect the change outcomes (Serina Al-Haddad Timothy Kotnour, 2015). Simply change management is a fuel to inject more power in business. The management and elected people have verified time to time that effective change management and leadership significantly influence the successful implementation rates of organizational initiatives/projects (Hornstein, (2015). AnderVoet, Groeneveld, and Kuipers (2014) differentiating leadership activities of planning and developing processes of change. Since change leadership is related to the higher leaps, that we need to make, related to propitious chances. 


\subsection{Counter resistance in change}

There are a number of approaches explaining resistance to change, which can be countered and make it simple to execute the change process. The strategies of neutralizing resistance to modify aren't constantly powerful but educative and persuasive. The entire idea of managing the resistance is standing up to change is made to get it the advantages of this adjust and the blessings that they and the overall organization could have whilst the proposed adjustments are executed (Fullan, 2001). These methods incorporate; practice and communication, help and inclusion, transaction and incorporation, manage as unambiguous in addition to understood impelling (Wagner, 1998).In order to understand the common sense backing resistance to exchange performed in academic organizations, it is crucial to think about the variety of resistance such as blind, political or ideological (Hambrick and Cannell 1989; as cited in Burke, 2008).

Higher management creates a more suitable environment in order to support the organizational individuals. For occurrence, it might create the staff members by creating a difference in their procedure for more aptitudes that are important and fundamental in implementing the changes, especially at the danger zone. Such practices are probably going to diminish protection from change (Dessler, 2001).

In arrange to form beyond any doubt that a change will be effective, school pioneers chose to be much specific on the people who are assumed to urge data, how much data, the exactness of that data, and when to spread the data (Fullan, 2007). Moreover, resistance to change may be diminished by giving the pioneers of standing up to bunch the most parts in choice-making approximately the change. This will offer assistance in recognizing their sees and making beyond any doubt that they propose something which they cannot stand up to (Bush \& Middlewood, 2005).

\subsection{Types of Resistance}

Education belongs to the service sector and entirely based on the number of students enrolled, and any of the other businesses can be satisfied or not depending on their priorities. Higher education is just like another formal education level in contrast to the social aspect. Nowadays it is often happening that institutes are effecting badly and sufferinga huge amount of challenges, problems and threats which are aroused from different internal and external variables that have the ability to change the shape of the business and set new dimensions for institutes, 
which entirely based on technological, IT and scientific development, and they introduce different comprehensive and skilled programs for modernization and development in the students that are enrolled in Arab education institutions. These steps are initiated in order to overcome the problem and weaknesses of institutes. Resistance to change (Lewis, 2019) may be of different types such as;

- Confusion resistance

- Political resistance

- Ideological resistance

\subsection{Causes of resistance to change}

In reality the resistance to accept change may take numerous shapes, it is difficult to recognize the reasons behind the resistance. The qualities against this change in the working environment consolidate ignoring the prerequisites and needs of the organization people; giving insufficient information around the nature of modifies and not recognizing the requirement for modify. In this way, people may appear fear and uneasiness over such things as security work, work levels, a mishap of work fulfillment, particular wage rates, confrontation of individual control over work and the changes occurring in the working environment (Mullins, 2005). In spite of the truth that modifies is actualized for positive reasons like changing to the unsuitable environment and remaining competitive, People belongs to the organization usually react to modify activities oppositely and stand up to change (Boohene \& Williams, 2012). The primary fact of this research is the negative reaction caused by weight, extend and flimsiness coming with change as following.

- Interference with need fulfillment

- Selective perception

- Habit

- Inconvenience or misfortune of freedom

- Fear of the unknown

- Knowledge and expertise obsolescence

- Organizational structure 
In organizations which have flawless management with progression of the specialist; work division and, directions, specializations and rules, a very less amount of structure are being given to bunch for satisfying the organizational goals.

\subsection{Overcoming resistance to change}

Critical factors include the project scope, size, and as well as personnel hierarchical position and experience levels (Canning \& Found,2015; Shimoni, 2017).There are nine change management factors that contribute to minimizing resistance to change,

1. Need to communicate a clear vision and mission to the management.

2. Top level management should need to lead this change.

3. Modify only appropriate elements of the organizational hierarchy.

4. Remove all the hurdles in communication between different departments.

5. Effective changes are required for individuals to accomplish missions.

6. Change and modify management performance measures and their tasks.

7. Set always new goals by comparing them in previous tasks.

8. Arrange training sessions

9. Adequate supply chain and resources

Resistance to change is the most critical phenomenon that should be addressed by the companies. Once management will identify the problems, the use of appropriate strategies and policies can reduce the resistance (Lines \& Mischung, 2015).These issues shape the extent of resistance to change which translates from the perception of, commitment to and involvement in the change process (Alkawaz \& Rehman, 2018).

Indeed, in spite of the fact that changes in an organization are supposed to modify in innovation, progression or in structures within the organization, it is apparent that change has colossal effect on people within an institute. In any case, the cause why numerous institutes fall flat to achieve change activities is related to thinking little of the impact of change on the person (Ashkanasy \& Kavanagh, 2006). Subsequently, dismissing mental recognitions of workers; lead toward disappointment of change activities in institutes (Buelens, Devos \& Bouckenooghe, 2007). In spite of the fact that, for fruitful change usage, it is vital to oversee the mental move of representatives viably (Martin \& Callan, 2005). 
It is important to feel that viable administration of changes entirely depending on understanding of humans in clear sense, conducted within the organization. Due to challenges and problems of these changes, people may respond with a few feelings like instability, disappointment

\subsection{Change benefits}

Change management is also a way to minimize resistance to change. Change as an organizational improvement enhances the morale, productivity and quality of work. The change also supports cooperation, collaboration and communication among the employees of an organization. A wellplanned methodology of change management reduces stress and anxiety and encourages loyalty among the employees of the organization. Change allows employees to learn new skills, explore new opportunities and exercise their creativity through increased commitment. Benefits of change management incorporate increased representative assurance, superior collaboration among divisions, bridging management-staff capacities, expanded quality from the client perspective and ceaseless improvement of each one who is the portion of higher education institutions (Al-Tarawneh, 2011). Quality in instruction may be or maybe a complex theme. What makes it such as the number of the parties included as well as the escalation of changes in advanced life.

\subsection{Behavioral Factors of Resistance to Change}

There have been discussed many reasons in the previous literature related to change management. The evidence about the factors of resistance is from different contexts and situations. However the researchers (Carlon et al., 2012: Jones, 2013; Goetsch, \& Davis, 2014) in early literature has discussed several factors responsible for resistance to change as follows:

- Not understanding and misunderstanding why the change is necessary for the organization. It is very much obvious from those employees who believe that their current working practices are doing well.

- Fear of the unknown: This is a common reason for resistance .This is just a risk perception of unknown factors that remains as an ambiguity in the understanding of employees. 
- Lack of competence: Personal incompetency is one of the reasons for resistance to change because people don't want to lose their position under the fear of being exposed as incompetent.

- Comfort with existing conditions: People become used to and comfortable with existing conditions and they have low trust in change. One of the common misperceptions is that the change process might be a temporary phenomenon.

- Poor participation: In many cases, this has been reported that people resist changing because they think that they have not been consulted. In this way, they have the sense of not having ownership and mistakenly they think change process as the agenda of some managers.

- Poor organizational leadership: Ineffective communication and absence of change leadership leads to weak change embracement. The role of leaders sometimes does not inculcate the real spirit of change in people. The main reason for this is poor communication and leader fails to connect people to an articulated vision and not able to connect employee's rewards with outcomes of change.

Oreg (2003) summarized the above factors to four main constructs and Al-Haddad \& Kotnour(2015) and Witting (2012) examined employees' reactions to organizational change and classified the following factors of resistance to change.

\section{Routine Seeking}

Routine seeking (RS) is an individual behavior of being staying in a state of existence for the long term. This is one of the effective components of resistance behavior because people are not ready for the short-term inconveniences" associated with change

\section{Emotional Reaction}

An Emotional Response to change as resistance is a situation mainly given to influence other individuals, groups or entities. Emotional Response is a variant of this spectra of emotions, Plutchik (1983) has proposed eight main emotional dimensions such as happiness vs. sadness, anger vs. fear, trust vs. disgust, and surprise vs. anticipation. These emotions can then be combined to create others ( such as happiness + anticipation $=$ excitement). 


\section{Short-term thinking}

Short -term thinking is a kind of permanent resistor. A short-term focus represents the degree to which the staff of an organization is preoccupied with short-term challenges. They are not aware of the reality of short-term objectives compared to long-term benefits of the change. Finkelstein et al. (1995) conducted a meta-analytical study on how employees are typically associated with short -term focused. He revealed that the lower potential for development compels them to stick with such thinking. The short-term focused employees may not relate themselves to more drive and readiness for change initiatives.

\section{Cognitive rigidity}

Cognitively relates to the act or process of knowing, and perceiving. The cognitive function, development and learning ae relating to the mental processes of perception, memory, judgment, and reasoning, as contrasted with emotional and volitional processes. According to Oreg (2003), the cognitive rigidity cognitive rigidity as a construct of resistance behavior represents reluctance to consider and test new perspectives and concepts. Change accepting behavior remains more cognitively and emotionally open to change initiatives taken by the management.

\section{Conclusion}

Change management is an emerging process phenomenon in many of the organizations globally. Change management is driven by many elements and results as the initiatives of the management. There are agreed benefits and advantages of change management for organizations and employees as well. At the same time, the change management process is experiencing some of the challenges. One of the major challenges is resistance to change management. This resistance is at the policy level, structural and behavioral level. The literature of common factors of resistance to change accounts for certain factors as main obstacles to the way of change. The literature review proposes the independent variables constructs such as, routine seeking attitude, emotional reaction, short term objectives, and cognitive rigidity. The dynamic nature of readiness for change is confronted by some of the key challenges in public sector organizations is quality administration. In many of the organizations this not administration approach effectively connected to the particular theme of quality management. The main contributor to the resistance factors is the scholastic culture of these organizations. 
The literature on factors of resistance provides the theoretical and conceptual guidelines for the current research. The main construct of resistance to change are taken as independent variables on the evidence from the literature.

\section{Research Methodology}

\subsection{Research approach:}

In order to determine the way of dealing with the current research, a deductive and inductive research approaches is used by the researcher to find out the results. These research approaches are very effective and can be easily used to carry out further tasks.

In this research study, the researcher has used inductive research approach which is not costly and give reliable results. Data is collected through different resources which is trustworthy. The random population also gives their recommendations to improve the processes as well (Pheng, 1997). The outcomes of this approach enable the researcher to make generalizations from specific (sample) to general (population).

\subsection{Research methodology}

There are so many findings that are based entirely on the actions of the researcher and they also depict the authenticity and reliability of the collected data. Research strategies are also helpful for the respondents so that authenticity and reliability could be maintained (Pheng, 1997). The research methodology is the particular or methods utilized to distinguish, select, prepare, and analyze data around a point. In a term paper, the strategy area permits the researchers to fundamentally assess a study's in general legitimacy and unwavering quality. Methodology refers to the study of how research is done and entails how we find out about procedures, and the manner of a research endeavor. This also outlines the principles that guide research practices. (Saunders, Lewis\& Thornhill, 2012).There is many research methodologies which can be used to find out the required results of the research. Research methodologies help the researchers to solve the problems at their earliest. Following are different research methodologies that could be used:

- Descriptive method.

- Experimental method.

- Exploratory method. 
In this particular research, the researcher has used descriptive method to find out the relevant results and this method is easy as compared to others. This research well described the characteristic of the sample and data. Furthermore, this is capable to describe the state of existence of variables and their relationship. In the second phase hypotheses are tested based on the co-relational phenomenon.

The quantitative research strategy is considered to be suitable for the current research on the following grounds.

- Appropriate and flexible to generate models, theories and hypotheses based on the exploration of the phenomenon.

- Collection of imperial data from a field study.

- Good provision for the data modeling

- Use of statistical packages in the analysis of data.

- Experimental control during the inquiry

- Manipulation of variables related to objectivity

- Instrument development for data collection.

- Prepare an appropriate measurement model suitable to answer to the research questions.

\subsection{Data Collection approach}

\subsubsection{Sampling:}

The target population is situated in a specific geographic concentration in Oman. In the current scenario, convenience samples are the most suitable method of drawing samples from the target population. One of the main advantages of this sampling is that sample represents the target population and eliminate sampling bias. The sample space is not large enough therefore a convenient sampling will be reasonable representative of the population. In a kind of basic study his method is reasonably good to get primary data.

\subsubsection{Population:}

The targeted population is the administrative staff and directors of departments in the Ministry of Education in Oman. 
Academic Journal of Research and Scientific Publishing | Vol 3 | Issue 33

Publication Date: 5-1-2022 ISSN: 2706-6495

\subsubsection{Sample size:}

Sample size refers to the number of observations and data units derived from a population. The size of the sample has impact on the significance of the results. Larger sample size refers to higher reliability. In the current case study, the sample is restricted in the General Directorate of Education in South Batinah Governorate, which has 9 main departments to administer the educational institutions in the area. The sample selection will be as follows:

\begin{tabular}{|c|c|c|c|c|}
\hline No & Departments & $\begin{array}{l}\text { Number of } \\
\text { directors } \\
\text { and } \\
\text { assistants }\end{array}$ & $\begin{array}{l}\text { Number of } \\
\text { heads of } \\
\text { sections }\end{array}$ & $\begin{array}{c}\text { The total } \\
\text { targeted sample } \\
\text { (each } \\
\text { department) }\end{array}$ \\
\hline 1 & DG office & 2 & 8 & 10 \\
\hline 2 & Financial Department & 1 & 4 & 5 \\
\hline 3 & $\begin{array}{l}\text { Administrative Affairs } \\
\text { Department }\end{array}$ & 1 & 4 & 5 \\
\hline 4 & Planning Department & 2 & 2 & 4 \\
\hline 5 & $\begin{array}{l}\text { Human resource development } \\
\text { Department }\end{array}$ & 4 & 7 & 11 \\
\hline 6 & $\begin{array}{l}\text { Educational assessment } \\
\text { Department }\end{array}$ & 3 & 3 & 6 \\
\hline 7 & $\begin{array}{l}\text { Educational Programs } \\
\text { Department }\end{array}$ & 3 & 4 & 7 \\
\hline 8 & Private School Department & 1 & 4 & 5 \\
\hline 9 & $\begin{array}{l}\text { Information Technology } \\
\text { Department }\end{array}$ & 2 & 4 & 6 \\
\hline 10 & $\begin{array}{l}\text { Project and Maintenance } \\
\text { Department }\end{array}$ & 1 & 3 & 4 \\
\hline & Totals & 20 & 43 & 63 \\
\hline & Grand total of sample & \multicolumn{3}{|c|}{63} \\
\hline
\end{tabular}


Academic Journal of Research and Scientific Publishing | Vol 3 | Issue 33

Publication Date: 5-1-2022 ISSN: 2706-6495

\subsection{Conceptual framework:}

The current study is based of change theory of kotter \& schlesinger (1989). The objective is to measure the level, reasons and significance of gender and experience on change resistance factors. Moreover, study examines the co-relational impact of resistance factors to implementation of the Quality Management System in the General Directorate of Education in South Batinah Governorate in Oman. The individual's perception plays an important role also play in the process of change. The reason creation of resistance is natural because perceived as a threat to one's security or ingrained habits loss of status or as fear of the unknown. Initially, this concept was developed by a (neck, 1996) that change will generate resistance. Therefore, based on assumptions of grounding theories and context of the research, the following research model is presented for current study

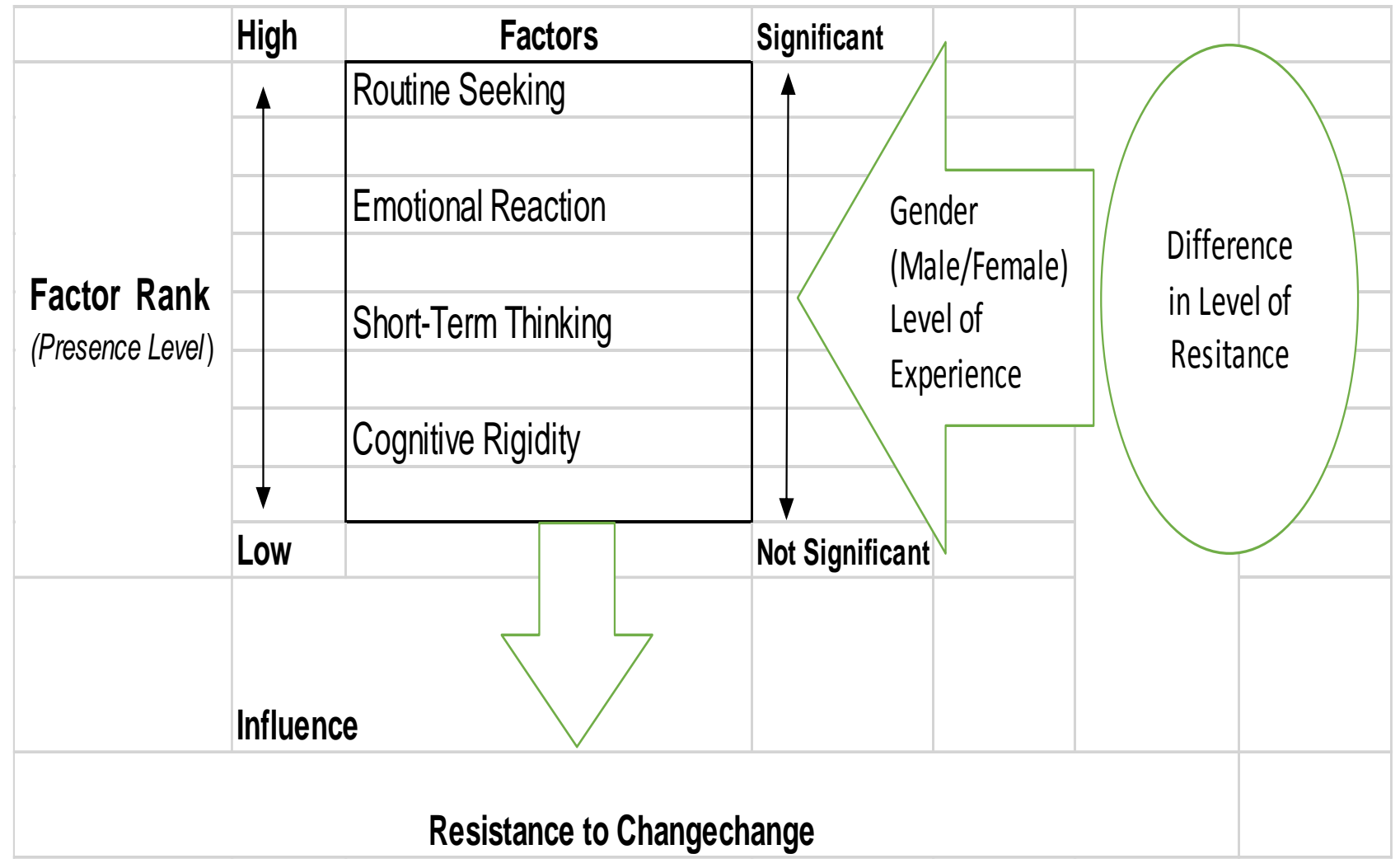

(Research Model)

\subsection{Development of Instrument}

The measurement of change management varies from one organization to another based on the business process. 
There are several studies guiding about the scale for measuring the change and effectiveness of change management. Measuring the effectiveness of change is a multi- dimensional spectrum.

The measurement items for resistance to change in this study were adapted from Oreg et al. (2008) who examined the equivalency of the resistance to change (RTC) scale across undergraduate colleges from 17 countries. The factors of predictions identified by RTC scale are routine seeking, emotional reaction, short-term thinking, and cognitive rigidity. Table below shows the factors and main items of the scale used in the study:

\begin{tabular}{|c|c|}
\hline Factor & Indicators \\
\hline \multirow{5}{*}{$\begin{array}{l}\text { Routine Seeking } \\
\text { (Oreg et al. ,2008) }\end{array}$} & - Changes to be a negative thing. \\
\hline & - Preference to routines \\
\hline & - Unlinking to do new tasks \\
\hline & - Impact of new tasks on routine life \\
\hline & - Boredom \\
\hline \multirow{6}{*}{$\begin{array}{c}\text { Emotional Reaction } \\
\text { (Oreg et al. ,2008) }\end{array}$} & - Feeling of stress \\
\hline & - Tense attitude \\
\hline & - Unfair feeling about evaluation criterions \\
\hline & - Uncomfortable with new tasks. \\
\hline & - Extra work without rewards \\
\hline & - Lack of Empathy \\
\hline \multirow{5}{*}{$\begin{array}{c}\text { Short-Term Thinking } \\
\text { (Oreg et al. ,2008) }\end{array}$} & - Changing a real hassle to me. \\
\hline & - Change has no potential to improve my life. \\
\hline & - Importance of immediate outcomes \\
\hline & - Personal benefits \\
\hline & - Change avoidance \\
\hline \multirow{4}{*}{$\begin{array}{l}\text { Cognitive Rigidity } \\
\text { (Oreg et al. ,2008) }\end{array}$} & - I often change my mind. \\
\hline & - Situation does not motivate \\
\hline & - Not changing mind easily. \\
\hline & - Consistency of views \\
\hline
\end{tabular}




\begin{tabular}{|c|l|}
\hline \multirow{2}{*}{ Factor } & \multicolumn{1}{|c|}{ Indicators } \\
\hline \multirow{4}{*}{$\begin{array}{c}\text { Implementation of } \\
\text { change } \\
\text { (Claver et al.,2003; } \\
\text { Wisner,1999) }\end{array}$} & $\bullet \quad$ Satisfaction of parents \\
\cline { 2 - 2 } & $\bullet \quad$ The role of change agents. \\
\cline { 2 - 2 } & $\bullet \quad$ Productivity of staff has improved. \\
\cline { 2 - 2 } & $\bullet \quad$ Quality of learning \\
\hline
\end{tabular}

The major purpose of this study which pointed out through the questionnaire was to find out the main factorlfactors that lead to resistance of change that influence the implementation of the Quality Management System in the Ministry of Education, by using specific direct and indirect statements. A 5-point rating scale has been used (Strongly Agree, Agree, Neutral, Disagree, Strongly Disagree).

\subsubsection{Validity}

The research instrument was reviewed by a group of specialists to investigate the external consistency of the items. Also the internal consistency statistically used to calculate the correlation coefficients between the items and overall mean of questionnaire. The coefficients of all items were significant at $(\alpha=0.01)$.

\subsubsection{Reliability}

Reliability level of the questionnaire was acceptable, (Cronbach's alpha=0.75) which indicates that we can use it.

\subsection{Analysis tools}

Following the data collection process, critically analyzed outcomes are essential for research. The data analysis is very important to provide an explanation of various concepts, theories, frameworks and methods used. Therefore, processing and manipulate data, analyze the relationships and correlations between data sets become easy through data analysis tools. Also, tools are helpful in identifying patterns and trends for interpretation. Initially, data was processed in MS Excel and PSPP (online free) software for analyzing descriptive and correlation data. 
The results have been analyzed based on the descriptive statistics, ranking of factors, t-test and ANOVA.

\subsection{Problems and limitations of approach}

The research study has some limitations where the researcher took care of ethical issues. Ethics would be considered very strictly while conducting different surveys and interviews. It is the responsibility of the researcher to take care of the ethical implications and management principles to carry out the tasks carefully. It should be taken care of very strictly that no one is harmed physically or emotionally while conducting the research (By \& Rune., 2005).

\subsection{Limitations of the study}

The current study has been conducted under the following limitations.

- Time constraints because the researcher has job commitments. Therefore, the study was limited to limited number of institutions.

- Focused at one place (South Batinah Governorate) and cannot be expanded to other places in Oman. Therefore, the generalization of the results of the study might be questioned.

- The sample size may have considered not large enough. Although it is not that much large, but satisfactory for analysis in order to satisfy statistical threshold requirements.

\subsection{Delimitation}

The current research is focused on a common phenomenon that is widely presented in the previous literature. Anyhow, to the extent of information on published data there were no studies found under the topic in the context of Oman. Therefore, setting the research objectives, questions and theoretical framework was a neutral activity. The topic has a broader scope but the current research is considered to be at an exploratory level and limited to major four factors independent variables. The selection of respondents is free from biased and purposiveness. First and basic research may lead to further clues of research in the same direction (Lee, 2010). The study has been conceptualized as of basic nature to guide to the further research in this topic.

\subsection{Ethical considerations}

Any inquire about examination including human subjects, there must use caution thought of ethical issues which will emerge within the arranging, conduct, 
Academic Journal of Research and Scientific Publishing | Vol 3 | Issue 33

Publication Date: 5-1-2022 ISSN: 2706-6495

And announcing of the ethical considerations in research are critical in conducting research. The current research has maintained the norms or standards for conduct that distinguish between right and wrong as following

- Data collection includes the informed consent from the Ministry of Education.

- The voluntary participation of participants was ensured without any influence on their independent opinion.

- Data presented in the current research was reported without any fabrication and alteration.

- The information of respondents and the original data were kept confidential and the same was communicated to the respondents in the questionnaire.

- Confidentiality of the data was assured to the participants

- The current research has ensured the anonymity 


\section{Findings and Analysis}

\subsection{Introduction}

This chapter presenting results of the study that aims at finding the impact of resistance to change on the implementation of Quality Management System in the Ministry of Education in Oman. As stated in the first chapter of this research, the study tried to answer the following four questions:

RQ1: What is the level of resistance to Implementation of Quality Management System (QMS) in the (MOE) of South Batinah based on staff and directors' perceptions?

RQ2: What are the factors that account higher to resistance to change?

RQ3: Is there any significant difference in opinion regarding resistance to Implementation of Quality Management System (QMS) in the (MOE) according to years of experience?

RQ4: Is there any significant difference in the opinion regarding resistance to Implementation of Quality Management System (QMS) in the (MOE) according to the educational level? Besides, this research has specific four objective derived from the research questions, as previously mentioned in the first chapter as follows:

1. To assess the level of resistance to Implementation of Quality Management System (QMS) in the $(M O E)$ by directors and staff perceptions.

2. To find out the factors of resistance that account higher to resistance and make recommendations to overcome the issue of resistance

3. To investigate the significant difference in the opinion regarding resistance to the implementation of Quality Management System (QMS)based on years of experiences.

4. To investigate the significant difference in opinion regarding resistance to Implementation of Quality Management System (QMS) according to years of educational level.

\subsection{Demographic characteristics}

The study sample consisted of (59) employees who works in the Ministry of Education in South Batinah governorate in Oman, only (54) of them correspond to the questionnaire due to the vacancies in some heads of departments. However, the total individuals (54 out of the total 59) was sufficient and expressive for calculating the data analysis. 
Academic Journal of Research and Scientific Publishing | Vol 3 | Issue 33

Publication Date: 5-1-2022 ISSN: 2706-6495

Table 1: Description of the participants according to gender, experience and education level.

\begin{tabular}{|l|l|c|c|c|c|c|}
\hline \multirow{2}{*}{ Education level } & \multirow{2}{*}{ Experience } & \multicolumn{4}{|c|}{ Gender } & \multirow{2}{*}{ Total } \\
\cline { 3 - 7 } & & \multicolumn{2}{|c|}{ Male } & \multicolumn{2}{|c|}{ Female } & \\
\hline \multirow{5}{*}{ Bachelor or less } & Less than 3 Yrs & 4 & $66.6 \%$ & 2 & $33.3 \%$ & 6 \\
\cline { 2 - 7 } & $4-5$ Yrs & 8 & $100 \%$ & 0 & $0 \%$ & 8 \\
\cline { 2 - 7 } & More than 6 Yrs & 9 & $90 \%$ & 1 & $10 \%$ & 10 \\
\cline { 2 - 7 } & Total & 21 & $87.5 \%$ & 3 & $12.5 \%$ & 24 \\
\hline Postgraduate & Less than 3 Yrs & 7 & $100 \%$ & 0 & $0 \%$ & 7 \\
\cline { 2 - 7 } & 4-5Yrs & 7 & $77.7 \%$ & 2 & $22.2 \%$ & 9 \\
\cline { 2 - 7 } & More than 6 Yrs & 14 & $100 \%$ & 0 & $0 \%$ & 14 \\
\cline { 2 - 7 } & Total & 28 & $93.3 \%$ & 2 & $6.6 \%$ & 30 \\
\hline \multirow{5}{*}{ Total } & Less than 3 Yrs & 11 & $84.6 \%$ & 2 & $15.3 \%$ & 13 \\
\cline { 2 - 7 } & 4-5Yrs & 15 & $88.2 \%$ & 2 & $11.7 \%$ & 17 \\
\cline { 2 - 7 } & More than 6 Yrs & 23 & $95.8 \%$ & 1 & $4.1 \%$ & 24 \\
\cline { 2 - 7 } & Total & 49 & $90.7 \%$ & 5 & $9.2 \%$ & 54 \\
\hline
\end{tabular}

Above -Table 1- shows that $90.7 \%$ participants were male and $9.25 \%$ female. This indicates that majority of the participants were male.

4.3 Research questions analysis:

RQ1: What is the level of resistance to Implementation of Quality Management System (QMS) in the (MOE) based on staff and directors' perceptions?

To answer this question, Mean and standard deviation were calculated for the scores of the study sample. The Mean was compared with the Assumed Mean of the scale whose value (3). Onesample t-Test used to indicate whether statistical significant difference existed between Mean and Theoretical Mean. Table (2) shows One-sample t-Test result.

Table 2: One-sample t-Test result.

\begin{tabular}{|l|c|c|c|c|c|}
\hline Variable & *Assumed Mean & Mean & $\mathrm{t}$ & $\mathrm{df}$ & Sig. (2-tailed) \\
\hline level of resistance & 3 & 3.15 & 3.23 & 53 & 0.002 \\
\cline { 2 - 6 }
\end{tabular}

* Assumed Mean= $($ Higher degree (5) + Lower degree (1) /2) 
The results in table 2 showed that there was significant difference at the $\mathrm{p}<.05$ level between the mean that calculated from sample individuals responses $(M=3.15)$ and the Assumed Mean (3), $t(53)=3.23, P=0.002$, therefore it can be concluded that the level of resistance to Implementation of (QMS) in the (MOE) based on staff and directors' perceptions is high.

The high level of resistance to change based on staff and directors' perceptions is due to several reasons

- The way of the QMS managing, precisely the process of documentation that takes time and effort within a very long and complex procedure. therefore, most of the respondents believe that QMS must be electronically systemized with all its documents to ease the continual upgrading of the forms.

- The ineffective role of the top management toward the QMS implementations.

- The misunderstood and ambiguity about how to deal with the QMS requirements

- The lack of training programs has impacted on the level of employees' perception (Quality Specialists)

- Lack of employees' competence in some departments.

Most of these reasons correspond with the researchers (Carlon et al., 2012: Jones, 2013; Goetsch, \& Davis, 2014) in literature review in this study.

\section{RQ2: What are the factors that account higher to resistance to change?}

To investigate the factors that lead to resistance to change this study takes Al-Haddad \& Kotnour(2015) and Witting (2012) of a four-factors model as follows:

1. Routine Seeking

2. Emotional Reaction

3. Short-term thinking

4. Cognitive rigidity

To come up with answering this question mean and standard deviation were calculated to determine factors that account higher to resistance to change. Table 2 shows the results. 
Table 3: Mean of factors that lead to resistance to change in the light of implementing QMS (items 6-25).

\begin{tabular}{|l|c|c|c|}
\hline Factors & $\mathbf{N}$ & Mean $(\mathbf{M})$ & Standard Deviation (SD) \\
\hline Cognitive Rigidity & 54 & 3.56 & 0.61 \\
\hline Emotional Reaction & 54 & 3.24 & 0.50 \\
\hline Short-Term Thinking & 54 & 3.23 & 0.49 \\
\hline Routine Seeking & 54 & 2.29 & 0.39 \\
\hline
\end{tabular}

Table (3) shows the mean of the factors that lead to resistance to change in the light of implementing QMS. The mean value ranged between (2.29-3.56), the highest of which was the Cognitive Rigidity $(M=3.56, S D=0.61)$, while the lowest factor was Routine Seeking $(M=2.29$, $\mathrm{SD}=0.39$ ). Figure 1 shows the difference between the factors mean, this indicates that Cognitive Rigidity account higher to resistance to change.

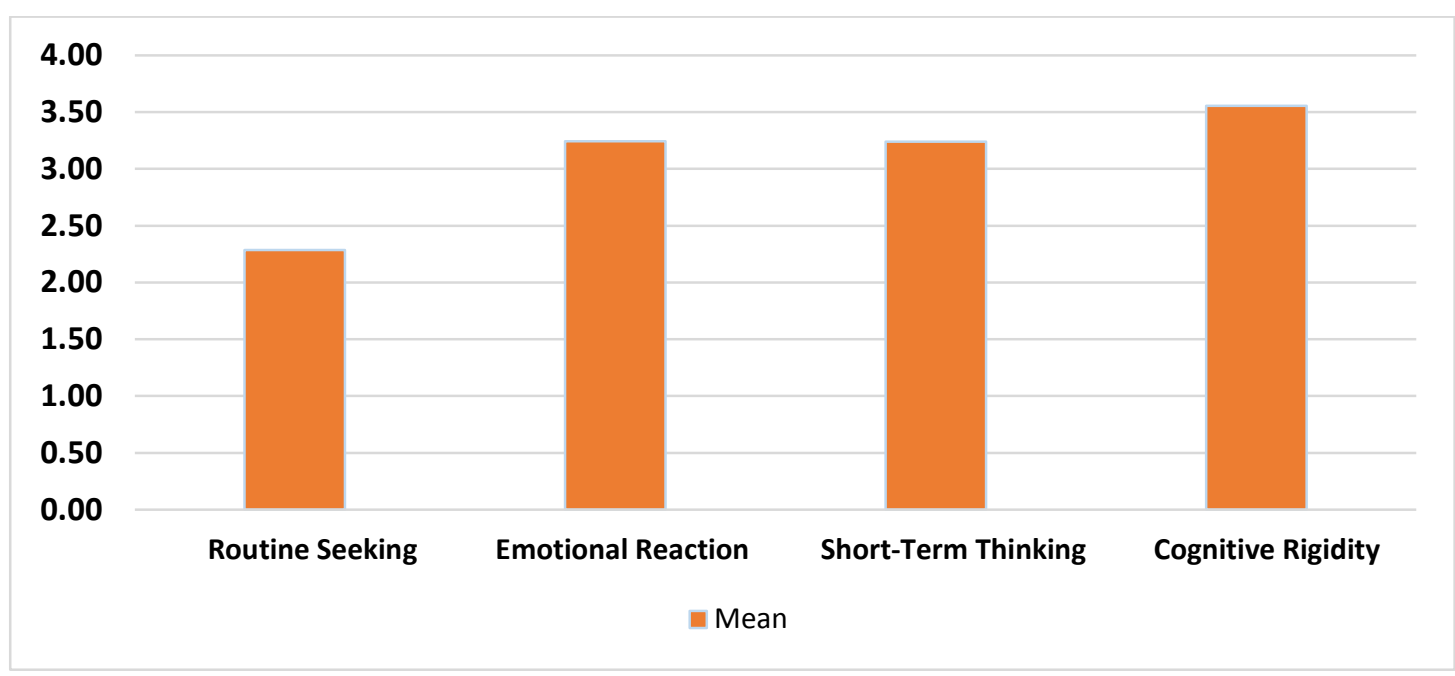

Figure 1: Mean of factors that lead to resistance to change in the light of implementing QMS

Figure 1 shows that the most of the four factors are closely impact the level of the resistance to change according to staff and directors' perceptions, cognitive rigidity factor is the highest because of the lack of intensive and systematic training, participation and involvement. The factor recorded the lowest level of resistance to change is routine seeking, therefore, This indicates that the employees have the readiness for change but they need support by setting some plans regarding the training programs and a very just welfare system to create a feeling of satisfaction to deal with the QMS. 
Academic Journal of Research and Scientific Publishing | Vol 3 | Issue 33

Publication Date: 5-1-2022 ISSN: 2706-6495

RQ3: Is there any significant difference in opinions regarding resistance to Implementation of Quality Management System (QMS) in the (MOE) according to years of experience?

One-way ANOVA was conducted to compare the effect of years of experience on Implementation of Quality Management System. There was no significant effect of years of experience on Implementation of Quality Management System at the $\mathrm{p}<.05$ level $[\mathrm{F}=0.98, \mathrm{p}=$ 0.382]. Table 3 shows One-way ANOVA results according to years of experience.

Table 4: One-way ANOVA of resistance to Implementation of (QMS) according experience

\begin{tabular}{|l|c|c|c|c|c|}
\hline Source of variance & Sum of Squares & df & Mean Square & F & Sig. \\
\hline Between Groups & 0.23 & 2 & .117 & & \\
\cline { 1 - 4 } Within Groups & 6.07 & 51 & .119 & .382 \\
\cline { 1 - 5 } Total & 6.31 & 53 & & & \\
\hline
\end{tabular}

Specifically, the results show that Implementation of Quality Management System (QMS) in the (MOE) does not change as the years of experience changed. Figure 2 illustrates the means of resistance in terms of the years of experience.

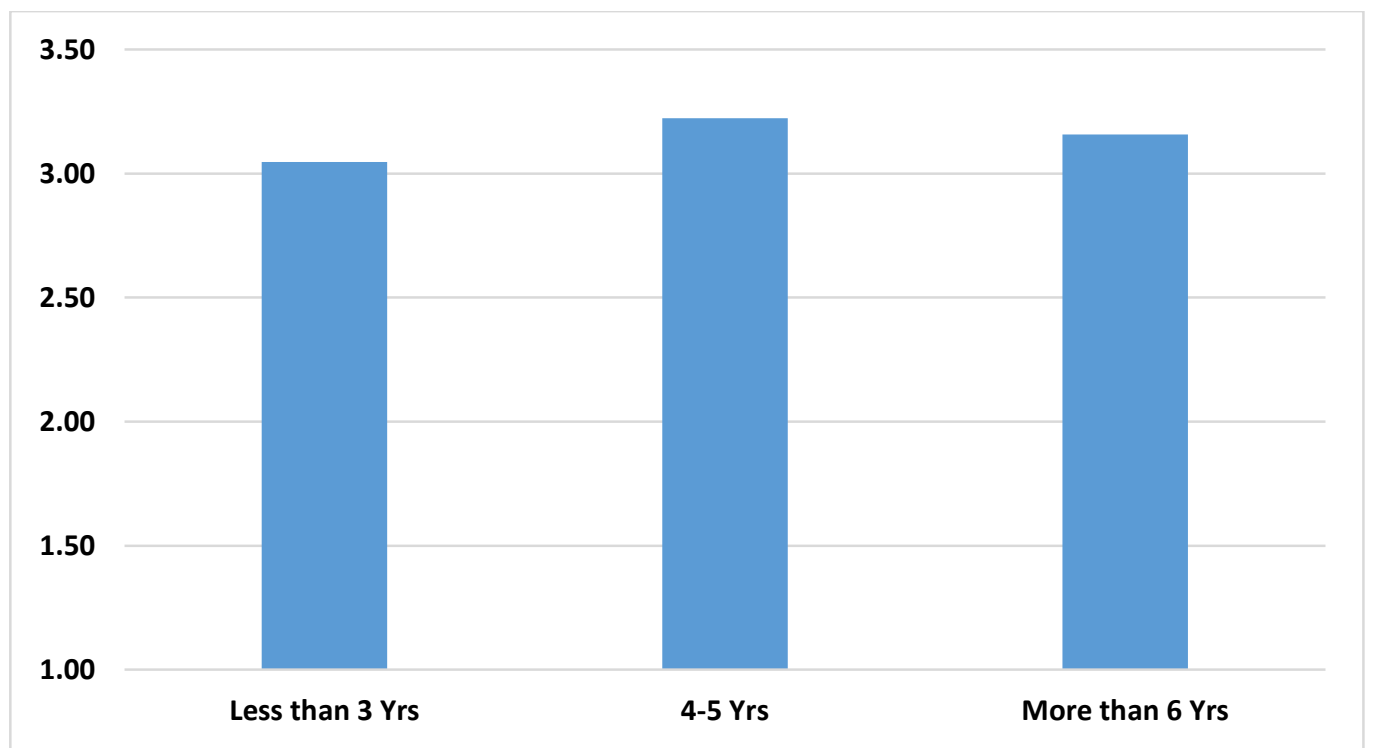

Figure 2: Mean of resistance to Implementation of (QMS) according experience 
Academic Journal of Research and Scientific Publishing | Vol 3 | Issue 33

Publication Date: 5-1-2022 ISSN: 2706-6495

RQ4: Is there any significant difference in opinions regarding resistance to Implementation of Quality Management System (QMS) in the (MOE) according to Educational level?

An independent sample t-test was conducted to determine whether there was a difference in opinions regarding resistance to (QMS) in the (MOE) according to Educational level. Table (4) shows the independent sample t-test.

Table 5: An independent sample t-test of difference in opinion regarding resistance to Implementation of (QMS)

\begin{tabular}{|l|r|r|r|l|r|c|}
\hline Educational level & N & Mean & Std. Deviation & t & df & Sig(2-tailed) \\
\hline Bachelor or less & 24 & 3.14 & .36 & \multirow{2}{*}{.192} & 52 & .849 \\
\cline { 1 - 5 } Postgraduate & 30 & 3.16 & .34 & & & \\
\hline
\end{tabular}

As noticed in Table 4, there was no significant difference in perception regarding resistance to Implementation of (QMS) between participants who have Bachelor or less $(\mathrm{M}=3.14, \mathrm{SD}=.36)$ and Postgraduate participants $(\mathrm{M}=3.16, \mathrm{SD}=.34) ; \mathrm{t}(52)=.192, \mathrm{p}=.849$.

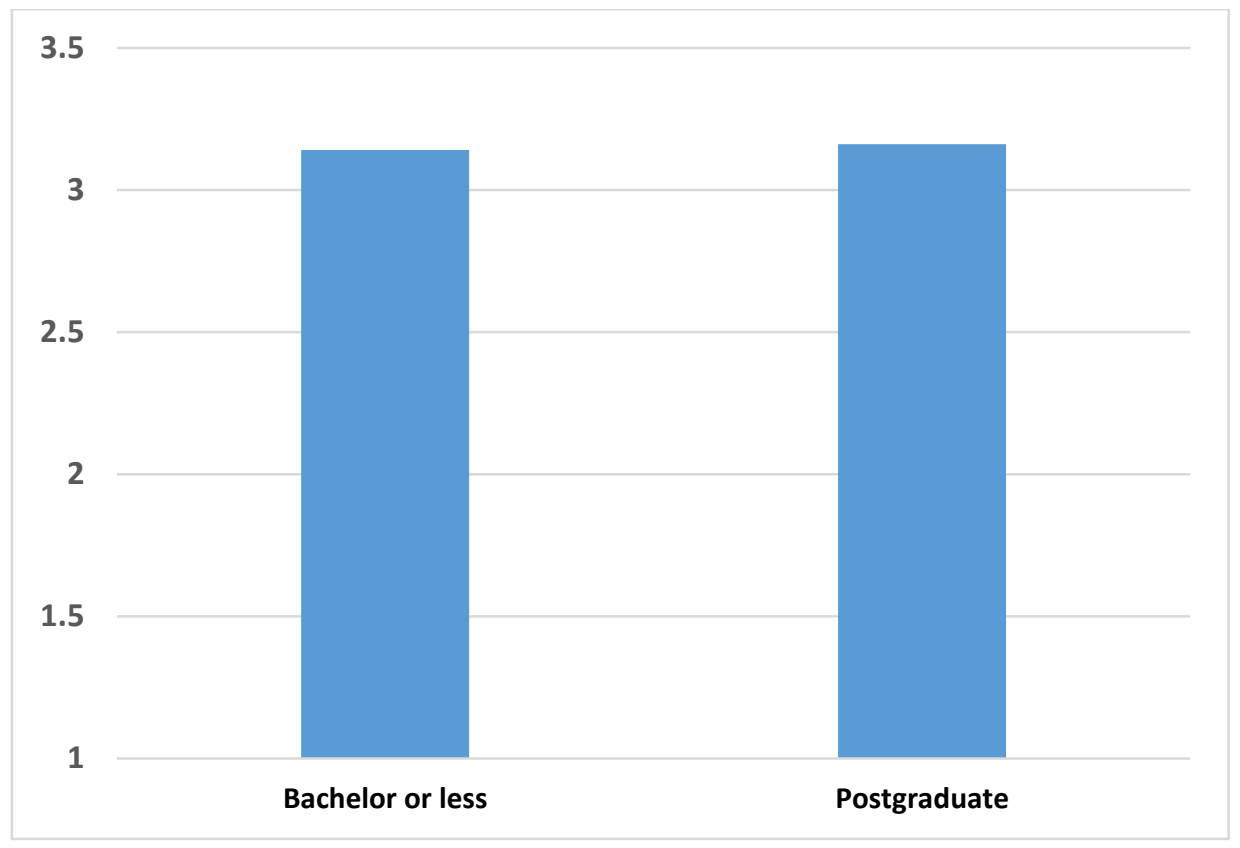

Figure 3: Mean of resistance to Implementation of (QMS) according to educational level It can be seen from Figure 3 that there are no differences in the resistance to implementation of (QMS) according to educational level. 


\section{Conclusion and Suggestions}

\subsection{Conclusion}

To conclude, issues of change in the organizations must have several considerations. Managing the change needs to consider several issues like the organizational structure, behavior, context, transparency and participation. The researcher tried to answer the four main questions stated in first chapter and to find out the main behavioral challenges behind the resistance to change while dealing with the QMS implementations in the Ministry of Education in Oman, also it studied the correlations between the impact of years of experience, level of education to the level of resistance to change. The instrument was used to investigate the problem is the questionnaire, the respondents were chosen from the heads and directors in the general Directorate of Education in south Batinah governance as a model of the study.

Statistical analysis pointed out that the level of resistance to change is high and cognitive rigidity factor has recorded the most behavioral impact, also the research questions 3 and 4 indicated with no significant differences of the years of experience and educational level of the respondents, however, the two factors statistically recorded a very closely results.

Accordingly, the Ministry of Education must follow a systematic plan to avoid the high level of resistance through setting intensive training programs beside a good welfare system to create an appropriate climate to make the employees encouraged to deal with new developments, also must prepare the top management leaders to take practical supportive actions to smooth the change procedures and to create general acceptance between the employees.

\subsection{Recommendations to overcome the resistance to change:}

1. There is a strong need of top management support toward the QMS implementations in the Ministry of Education.

2. The Ministry of Education must have a clear and systematic training plan for all employees in the different administrative levels to make a clear vision on how to deal with the QMS requirements.

3. The QMS must cope with the technical requirements to unify the documentation process and control the distractive procedures.

4. Set a plan to investigate the reality of the work in the different departments and find the challenges to make the QMS smoothly implemented. 
5. There must be a very skillful and competent reference to deal with the nature of the QMS requirements.

6. Overcoming the gap between the theoretical and practical part of the QMS.

7. Flexibility is required within the scope of the regulations and official design.

8. Decentralizing the QMS implementation is must to have more productivity.

9. There must be a bridging between the theoretical part and the practical part of the QMS implementation.

10. The MOE need to have a clear vision on how to change the organizational culture to pave the way towards the employees' performance and production.

\section{References}

- Al-Tarawneh, H., \&Mubaslat, M. (2011). The implementation of total quality management (TQM) on the higher educational sector in Jordan. International Journal of Industrial Marketing, 1(1), 1-10.

- Ali, M. M., Abdulhamed, K. R., \& Humaidalwaili, (2015). Actuality of Applying Total Quality Management in Omani Schools. International Journal of Scientific \& Technology Research (4)11.

- Al-Haddad, S., \& Kotnour, T. (2015). Integrating the organizational change literature: a model for successful change. Organizational change management.

- Alibabić, Š . (2010). Change management-andragogical professional challenge. Adult Education: The Response to Global Crisis Strengths and Chalenges of the Profession, str, 109-127.

- Alkawaz, M. H., Sulong, G., Saba, T., \&Rehman, A. (2018). Detection of copy-move image forgery based on discrete cosine transform. Neural Computing and Applications, 30(1), 183-192.

- Anderson, D., \& Anderson, L. A. (2010). Beyond change management: How to achieve breakthrough results through conscious change leadership (Vol. 36). John Wiley \& Sons. 
- Andrade, J. L. (2017). Perceived psychological empowerment and total quality management-based quality management systems: exploratory research. Total Quality Management \& Business Excellence 28.1-2, 76-87.

- Boohene, R., \& Williams, A. A. (2012). Resistance to organisational change: A case study of Oti Yeboah Complex Limited. International Business and Management, 4(1), $135-145$.

- Brookes, M., \& Becket, N. (2007). Quality Management in higher education: a review of international issues and practice. International Journal of Quality Standards, 1(1), 85 121.

- Burke, W. W., Lake, D. G., \& Paine, J. W. (Eds.). (2008). Organization change: A comprehensive reader (Vol. 155). John Wiley \& Sons.

- Bush, T., Middlewood, D., Morrison, M., \& Scott, D. (2005). How Teams make a Difference? The Impact of Team Working.

- Cameron, E., \& Green, M. (2019). Making sense of change management: A complete guide to the models, tools and techniques of organizational change. Kogan Page Publishers.

- Canning, J., \& Found, P. (2015). Resistance in Organisational Change. International Journal of Quality and Service Sciences, 7(2/3), 274-295.

- Carlon, D., Downs, A., Pieterse, J. H., Caniëls, M. C., \& Homan, T. (2012). Professional discourses and resistance to change. Journal of Organizational Change Management.

- Dessler, G., Starke, F. A., \& Cyr, D. J. (2001). Management: Leading people and organizations in the 21st century. Upper Saddle River, NJ: Prentice Hall.

- Devos, G., Buelens, M., \&Bouckenooghe, D. (2007). Contribution of content, context, and process to understanding openness to organizational change: Two experimental simulation studies. The Journal of social psychology, 147(6), 607-630. 
- Finkelstein, L.M., Burke, M.J. and Raju, N.S. (1995), “Age discrimination in simulated employment contexts: an integrative analysis", Journal of Applied Psychology, Vol. 80 No. 6, pp. 652663.

- Forrester, D., McCambridge, J., Waissbein, C., Emlyn-Jones, R., \& Rollnick, S. (2007). Child risk and parental resistance: can motivational interviewing improve the practice of child and family social workers in working with parental alcohol misuse?. British Journal of Social Work, 38(7), 1302-1319.

- Fullan, M. (2001). The new meaning of educational change. Routledge.

- Goetsch, D. L., \& Davis, S. B. (2014). Quality management for organizational excellence. Upper Saddle River, NJ: pearson.

- Hornstein, H. A. (2015). The integration of project management and organizational change management is now a necessity. International Journal of Project Management, 33(2), 291-298.

- Issan S, Gomaa N (2010). Post Basic Education Reforms in Oman: A Case Study. Lit. Inf. Comput. Educ. J. 1(1). Learning Point Associates (2004). Guide to Using Data in School Improvement Efforts: A Compilation of Knowledge From Data Retreats and Data Use at Learning Point Associates. www.learningpt.org. retrieved on December10, 2019.

- Jones, G. R. (2013). Organizational theory, design, and change. Upper Saddle River, NJ: Pearson.

- Kane, H., Ragsdell, G., \& Oppenheim, C. (2006). Knowledge management methodologies. The Electronic Journal of Knowledge Management, 4(2), 141-152.

- Kavanagh, M. H., \&Ashkanasy, N. M. (2006). The impact of leadership and change management strategy on organizational culture and individual acceptance of change during a merger. British journal of management, 17(S1), S81-S103.

- Kotter, J. P., \& Schlesinger, L. A. (1989). Choosing strategies for change. In Readings in strategic management (pp. 294-306). Palgrave, London. 
- Leavitt, H. J., \& Bass, B. M. (1964). Organizational psychology. Annual review of psychology, 15(1), 371-398.

- Lewis, L. (2019). Organizational change. John Wiley \& Sons, Incorporated.

- Lines, B. C., Sullivan, K. T., Smithwick, J. B., \&Mischung, J. (2015). Overcoming resistance to change in engineering and construction: Change management factors for owner organizations. International Journal of Project Management, 33(5), 1170-1179.

- McFadden, M. A., Patterson, W. P., Mullins, H. T., \& Anderson, W. T. (2005). Multiproxy approach to long-and short-term Holocene climate-change: evidence from eastern Lake Ontario. Journal of Paleolimnology, 33(3), 371-391.

- Ministry of Education (2014). National Report on Quality Education in Oman. Ministry of Education, Muscat, Sultanate of Oman

- Nasser, R. (2019). Educational Reform in Oman: System and Structural Changes. In Education Systems around the World. IntechOpen.

- Neck, C. P. (1996). Thought self-leadership: A self-regulatory approach towards overcoming resistance to organizational change. The International Journal of Organizational Analysis, 4(2), 202-216.

- Oreg, S. (2003). Resistance to change: Developing an individual differences measure. Journal of Applied Psychology, 88(4), 680-693.

- Peiffer, S. E. (2016). "The Impact of Human Factors on a Hospital-Based Quality Management System. The Journal for Quality and Participation 39.3, 19

- Pheng, L. S. (1997). Quality management systems: a study of authority and empowerment. Building Research \& Information 25.3, 158-169.

- Plutchik, R. 1983. Universal problems of adaptation: Hierarchy, territoriality, identity, and temporality. In: Environment and population: Problems of adaptation, ed. Calhoun, J.B. New York: Praeger. 
- Pratasavitskaya, H., \& Stensaker, B. R. (2010). Quality management in higher education: Towards a better understanding of an emerging field. Quality in Higher Education, 16(1), 37-50.

- Pratasavitskaya, H., \& Stensaker, B. R. (2010). Quality management in higher education: Towards a better understanding of an emerging field. Quality in Higher Education, 16(1), 37-50.

- Rosa, M. J., Sarrico, C. S., \& Amaral, A. (2012). Implementing quality management systems in higher education institutions. Quality assurance and management, 129-146.

- Sallis, E. (2014). Total quality management in education. Routledge.

- Saunders, M., Lewis, P. \& Thornhill, A. (2012) "Research Methods for Business Students" 6th edition, Pearson Education Limited.

- Shimoni, B. (2017). What is resistance to change? A habitus-oriented approach. Academy of Management Perspectives, 31(4), 257-270.

- Todnem By, R. (2005). Organisational change management: A critical review. Journal of change management, 5(4), 369-380.

- UNESCO (1998, October). Declaracao Mundial Sorbe Educacao. Retrieved December, 2019, from http://unesdoc.unesco.org/images/0014/001419/141952e.pdf.

- Van Dam, K., Oreg, S., \& Schyns, B. (2008). Daily work contexts and resistance to organisational change: The role of leader-member exchange, development climate, and change process characteristics. Applied psychology, 57(2), 313-334.

- Weiner, S., \& Wagner, H. D. (1998). The material bone: structure-mechanical function relations. Annual review of materials science, 28(1), 271-298.

- Wittig, C. (2012). Employees' reactions to organizational change. Od practitioner, 44(2), 23-28.

- Yılmaz, D., \& Kılıçoğlu, G. (2013). Resistance to change and ways of reducing resistance in educational organizations. European journal of research on education, 1(1), 14-21. 
- Yılmaz, D., \& Kılıçoğlu, G. (2013). Resistance to change and ways of reducing resistance in educational organizations. European journal of research on education, 1(1), 14-21.

Copyright (C) 2022 Mr. Hamed Salim Said AL Basami, AJRSP. This is an Open-Access Article Distributed under the Terms of the Creative Commons Attribution License (CC BY NC) Doi: https://doi.org/10.52132/Ajrsp.e.2022.33.2 